\title{
Local Wisdom and Sumatran Tiger in Leuser-Ulu Masen Landscape: A Study in Mane Sub-district of Aceh Province
}

\author{
Ali Bangun Gea', Badaruddin², Ma'rifatin Zahrah ${ }^{3}$ \\ \{alibangungea@gmail.com ${ }^{1}$, badaru_69@yahoo.com ${ }^{2}$, titienmirza@yahoo.com ${ }^{3}$ \} \\ ${ }^{1}$ Student of Natural Resources and Environmental Management, Post-graduate School, University of \\ Sumatera Utara, Jl. Prof. Maas No.1 Kampus USU, Medan, North Sumatra, Indonesia \\ ${ }^{2}$ Faculty of Social and Political Science, University of Sumatera Utara, Indonesia \\ ${ }^{3}$ Faculty of Forestry, University of Sumatera Utara, Indonesia
}

\begin{abstract}
Leuser Ulu-Masen landscape is considered to be a very important habitat for Sumatran Tiger. Mane Sub-district in Aceh Province, part of Leuser-Ulu Masen landscape, is identified as an area that has strong local wisdom characteristics in forest management. The objectives of this research were to analyze the perception of local community to the existence of tiger, analyze local wisdom arising from the presence of tigers, analyze mitigation of local community to human-tiger conflict in our study area. Hunting of all wildlife in this forest area is strictly prohibited. We realized role of customary law which prohibits wildlife hunting activities will have a good impact on the conservation of Sumatran tigers. We strongly recommend this model of natural resource management in our research location (based on good local wisdom) be implemented in other areas, especially in areas that have high human-tiger intensity and high density of tiger in human-dominated area.
\end{abstract}

Keywords: Sumatran Tiger, Leuser-Ulu Masen, local wisdom, Mukim Lutueng, tiger aceh.

\section{Introduction}

Tiger conservation is critically important for Indonesia. As the charismatic megafauna [1], [2], tiger can be used to achieve environmental conservation goals in the world as flagship and umbrella species in a forest ecosystem. After the Balinese tiger (Panthera tigris balica) and Javan tiger (Panthera tigris sondaica) were declared extinct [3], [4], Sumatran tiger (Panthera tigris sumatrae) is the last subspecies that only lives in wild on the Indonesian island of Sumatra [5]. The importance of Sumatran tiger conservation is quite extensive from the standpoints of ecology, politics, law and policy, socio-cultural, economic and for scientific purposes [6]. Conservation programme for Sumatran tiger is a must. In our National Tiger Recovery Program (NTRP), Indonesia has committed to doubling tiger population and protect their habitats in several tiger conservation landscape priorities [7].

Leuser Ulu-Masen landscape is considered a very important habitat for Sumatran Tiger. This 'global priority' landscape is the largest habitat $( \pm 3,3$ million ha) and have more than 100 Sumatran tiger individuals living in wild, which has the potential for long-term survival [8]. Most of these landscapes are in Aceh Province, so it can be recognized that Leuser-Ulu masen is a forest cover in Aceh province. Since 2010, Aceh Province has been categorized as one of the provinces with the highest level of human-tiger conflict (HTC) [5]. Therefore, reducing conflict between humans and tigers caused by humans can be an important factor in the success of tiger conservation [9], [10], especially by knowing how the local community behaves around the tiger habitat. 
Tiger is a cryptic species that has been integrated with the social life of people who live in the Aceh forest area. The occurrence of Human-Tiger Conflict is one of the negative impact of tiger presence in humandominated landscape. But the positive impact can formed good local wisdom. The relationship between humans and tigers will form local wisdom in the area. Not all Acehnese people have local wisdom in managing forests, especially that included in their Qanun.

Mane sub-district in Aceh Province as part of Leuser-Ulu Masen landscape is identified as an area that has strong local wisdom characteristics in forest management. Mane Subdistrict, in the Pidie District of Aceh Province, is one of the areas within the Leuser-Ulu Masen landscape that already has local wisdom based forest management. Forest management based on local wisdom is found in forest management activities, there are recommendations and prohibitions and customary institutions [11]. Mane sub-district already has a Village Forest Management permit that is broad enough so that the community has a high level of responsibility and awareness for forest sustainability. We have identified that $85 \%$ of this area is a protected forest area that has the potential as habitat for wild tigers. We are interested to find out more, because this area is included in the Leuser-Ulu Masen Landscape but it is not a conservation area.

The objectives of this research were to analyze the perception of local community to the existence of tiger, analyze local wisdom arising from the presence of tigers around their forests, analyze mitigation of local community to human-tiger conflict in our study area. We hoped this research can become a reference to tiger conservation programme the relationship between the community and tigers in areas with low conflict intensity in the Leuser-Ulu Masen landscape.

\section{Methodology}

This study is a descriptive research. We combined quantitative and qualitative methods. Quantitative method was done by scoring the questionnaires offered to respondents, while qualitative methods done by observation and deep interview to our informants. This research was conducted from December 2018 to May 2019. The study area located in Mane Sub-district, District of Pidie in Aceh Province of Indonesia. Our study area covers 4 villages, with total area of $\pm 67,959$ ha including $\pm 85 \%$ of protected forest that is suitable for tiger habitat.

The population in this study area consists of 2,607 families. We used 100 respondents as samples which were chosen proportionally based on the percentage of the number of families in each village : 1) Blang Dalam $=476$ families; $18 \%$, 2) Lutueng $=454$ families; $17 \%$, 3) Mane $=1,260$ families; 48\%, 4) Turue Cut $=417$ families; $16 \%$. We also choosed respondents purposively by these criterias : 1) lived within $0.5 \mathrm{~km}$ of the forest, 2) has a garden or rice field $0.5 \mathrm{~km}$ from the forest, 3) have activity going into forest, 4) have livestock that can be prey to tigers (buffalo, cow, chicken, duck, etc.).

To support qualitative approach, we used observation and deep interview with informants. Our informants are : 1) staff of BKSDA Aceh, as the authorities in charge of animal affairs, 2) FFI-IP Aceh, NGOs that has work programs on various matters in our study area, 3) local public figures, including Head of sub-district, Imuem Mukim Lutueng (Customary leader), Village head, Youth figures, 4)Pawang harimau Aceh (a tradional tiger tamer in Aceh).

The questionnaire that we used adopted socio-ecological methods [12], but in this paper we only analyzed 2 predictors to measure respondent's perception on the tiger, tolerance and norms. We only use one question per predictor. On the question in Tolerance section, we used Five-point Likert response 'Strongly agree' to 'Strongly disagree' scaled from 1-5, while in norms predictors we used opposite scaled value. Furthermore, using this method, we categorized the score greater than neutral value into pro conservation behaviour. We used Ms. Excel to count frequency, distribution, average score and percentage value.

In this research, we collected population and administrative data in our study area, profiles of respondents, result data from our questionnaire, SOP to effort the Human-Tiger Conflict (HTC) in Aceh Province [13], and Customary Law in Mukim Lutueng Subdistrict Mane [14]. In Indonesia the terms Mukim and Qanun are only found in Aceh Province as part of their local wisdom existence. In our study, Qanun means a local law under the special autonomy, while Mukim means customary community which oversees several villages in a subdistrict. 


\section{Result and Discussion}

\subsection{Profile of Respondent}

Furthermore, none of local community hate or hold a grudge against the tiger. The local community usually respects tigers and considers The mean age of respondents was 48 years, $59 \%$ of them was in age range 36-55 years. We also surveyed several daily activities from the respondents: $85 \%$ farming; $92 \%$ gardening; $78 \%$ doing activities into the forest; 59\% having livestock. All of our respondents werw Acehnese and Muslims. In generally, the people who live in Aceh Province of Indonesia (Acehnese and Muslims) are very obedient in carrying out Islamic teaching, so it can be involved to encourage conservation action [15]. The role of Islam can greatly influences their attitudes and behavior towards wildlife in our study area.

\subsection{The Most Disturbing Wildlfe}

We have asked a simple question from respondent to find out the most disturbing wildlife that bothered and costing the local community in study area. Our result said elephant $(68 \%)$, tiger (11\%), other wildlife including bias answer (8\%), and not feel bothered by wildlife (13\%). Based on the result, we can see the $87 \%$ of respondent feel bothered of the existence of the wildlife near their forest. Other research shows our study area have intensities of Human-Elephant Conflict, it usually occurs at night [16], [17]. We found that elephant conflicts have an impact on local community adaptation in dealing with human-wildlife conflict in generally, including their mitigation effort to human-tiger conflict. Conflict management efforts with wildlife are carried out in accordance with existing local wisdom, namely by eviction by using firecrackers.

\subsection{Perception of Local Community in Tolerance and Norm to Catch Tiger}

Our question in tolerance section was 'Do you agree tiger living in this forest near your village ?'. The response: Strongly agree (5\%), Agree (50\%), Neutral (33\%), Disagree (3\%), Strongly disagree (12\%). The average score was 3,27 indicates pro conservation behaviour. We know that tolerance can't be measured by only offering one question. Based on our observations and interviews with informants, it is known that there is no indication that the community does not tolerate the presence of tigerstigers to have a direct benefit.

In norm section, we used this question 'Do you agree if someone ask you or one of your family members to catch the tiger ?'. The response are Strongly agree (4\%), Agree (4\%), Neutral (11\%), Disagree (60\%), Strongly disagree $(21 \%)$. The average score was 3,9 indicates pro conservation behaviour. The extinction of the Javanese Tiger and the Balinese Tiger as a tiger subspecies in Indonesia tend to be caused by massive poaching activities [6]. Although until now the trade in all parts of the tiger body is prohibited [3], [18], but there are still some people who want it. Then a high norm value (agreeing not to hunt tigers) is needed for people who live around tiger habitat. The existence of norms prevailing in these communities can be utilized to encourage changes in human behavior towards tigers [19]. Based on data from our informant, there has been no record of cases of tigers entering a snare, tigers were killed until indications of the tiger trade network. We realize that this makes sense, because in addition to the results of quantitative surveys and the application of local customary rules, also because tigers are very difficult to detect. Thus reducing the attention of tiger poacher to hunt.

All the average scores on the questionnaire exceeded the neutral value which was interpreted as proconservation behaviour. The norm in the form of a prohibition against hunting all wild animals was existed in our study area and implemented well. Even violations of these rules are also subject to strict sanctions. One of the sanctions imposed is in the form of a fine with an amount of money. Based on this, the decline in tiger population caused by hunting activities does not occur around Mane sub-district.

\subsection{Tiger and Local Wisdom}

Tiger is rarely seen by local community, but they believe its existence living in their forest. We realized our study area do not have high tiger density and seems tiger population is not increased in this part of LeuserUlu Masen. Based on our observation, $85 \%$ protected forest in the study site is still suitable to be inhabited by wild tigers. The study shows gaining information for cryptic species living at low densities across large areas has previously proved difficult [1]. As almost part of our study area is protected forest and part of Leuser-Ulu Masen the largest habitat of wild Sumatran tiger, conflict to tiger is also rarely happened. In accordance with the information of the informants stated that there has not been a survey conducted to find out the number of tiger populations around the study site a presence survey, the results of which indicate the presence of tigers is 
still positive. We also learned that it is very difficult to conduct population survey because of the intensity of the people who use the forest for their livelihoods, climate conditions that rain all day and the nature of tigers that constantly adapts and avoids human presence. Our informants also mentioned that there have been no cases of tiger catching at the study site, even the community was called upon to damage the snares that were seen when entering the forest. We assume that tigers try to adapt to their habitat and avoid human existence.

In general, local wisdom is the local ideas that are wise, full of wisdom, good value, which is embedded and followed by members of the community. Local wisdom also contains local cultural wisdom. Local cultural wisdom itself is a local knowledge that has been so integrated with the belief system, norms, and culture and expressed in traditions and myths embraced in the long term [20]. Based on interview of informants, the local community thinks that presence of tiger in their area brings good impact to them. Here we describe the local wisdom related to the tiger in our study area :

1. The local community do not feel bothered by the existence of tigers. It began when their ancestors and the tigers both lived in a forest area made an agreement to not bothering each other. If the tiger bother the local community, then as the consequence the tiger will be difficult to get food for up to 40 days. Vice versa, if the local community bother the tigers then the tigers will come into their villages, attacking livestock and human or at least damaging village that can be costly for the local community. That consequence can be called as Human-Tiger Conflict (HTC). So based on the story as their local wisdom, HTC can be occurred if one of them (tiger or human) breaking the agreement (rule).

2. Tigers eat durian neater than humans. Sometimes tigers eat durian, although tigers are actually carnivorous animals. It is marked by the former durian which is opened using scratches and arranged neatly. if there are people who eat durian in a mess means the ethics is worse than animals (tiger).

3. Tigers that live in the forest are considered to be of benefit to the community because wild boars will not enter their villages. Based on the simple understanding of the local community that wild boars are tiger preys. local community who are predominantly Muslim consider wild boars to be disgusting animals, can harm agricultural activities because they are considered pests, but still may not be killed. Therefore, if wild boars enter the settlement, it shows that the tiger is no longer presence in the surrounding forest.

Based on the explanation, it can be seen that the values of local wisdom towards tigers arising in the middle of the local community have a positive impact on the social life of the community itself. However, not all people know and realize the meaning of those local wisdom. Usually stories about tigers based on local wisdom will be more often found in areas that have high human-tiger conflict intensity. So it is possible to find stories that are similar but local people interpret them with different things according to their local wisdom.

We also discovered that there are customary rules which prohibit all wildlife hunting activities. The consequence of violating this is to impose a fine of at least 5 million rupiah ( \pm 355 USD) and to confiscate equipment and hunting results. These fines are usually used for local youth activities such as sports and are not used for activities related to religion. Therefore, the community, especially the local youth, plays an active role in monitoring violations of customary rules.

The customary rules also have a role in protecting the forest as a tiger habitat. Illegal logging is strictly prohibited and only allowed to cut trees under certain conditions and rules. Planting oil palm is also strictly prohibited and the local community is encouraged to damage the snares when they enter the forest. The traditional wisdom of the local community is often a very useful rule for conservation.

\subsection{Human-Tiger Conflict Mitigation}

BKSDA of Aceh Province as an authority states that there are 7 activities that can trigger the occurrence of Human-tiger conflict [13], they are 1) Small and large scale plantations, 2) Collection of NTFPs (NonTimber Forest Products), 3) Community mining and large scale mining, 4) Tiger prey hunting (deer, deer, wild boar), 5) tiger poaching, 6) Illegal logging, 7) Animal husbandry and grazing in forest areas. We only found 2 activities, the existence of small-scale plantations (1) and the collection of NTFPs (2). In Aceh Province, they define Human-tiger conflict only if it occurs outside the forest area.

After our observation and interview with our informants, we found the existence of local community effort to handle human-tiger conflict. Mitigation efforts in residential areas are done by making waist-high boundary fences for adults. In addition to preventing the entry of wild animals, the fence also functions as a boundary for the community's own land. Other mitigation efforts carried out in residential areas are with the recommendations and restrictions on livestock management. Cattle grazing is determined by the function of a certain area called Padang Meurabe (grassland) and don not allow cattle to roam at night. The local community 
realize tiger and elephant are active at night. Likewise, the intensity of conflicts with elephants generally occurs at night [16], [17].

People who go to the forest make mitigation efforts by carrying wooden sticks that are used when walking. Basically the use of wooden sticks is intended as a sound trigger, so tigers will avoid it. Based on local wisdom, mitigation efforts can be interpreted that these efforts are not something that can have a negative impact on tigers and can also function as an effort to mitigate conflicts with wildlife in general. In tackling conflicts with tigers, through representatives of community leaders in Mane Subdistrict, they have prepared several firecrackers as an eviction attempt if wildlife enter the village. Use of the traditional tamer is also used in conflict scenarios with wildlife, the role of traditional tamer in our study area is someone who understands better how to relieve the anger of the community to prevent a grudge for local communities and give a prayer so that the wild animals will not interfere again. However, community efforts to tackle conflict with tigers independently have never been done, because the intensity of conflict with tigers is very rare around our study area.

\section{Conclusion}

The average score of the quantitative survey is related to local community perception of the existence of Tigers that has been carried out is 3.40 , which means it exceeds the neutral value of the weighing 1-5. Even though the average score is good, but it's not very strong. Strengthening people's perceptions to show more proconservation behavior through religious approaches (Islam) is a good possible recommendation.

We found the dynamics of local community wisdom arising from the presence of tigers that have a good impact on the perception of their social life. Local wisdom usually arises from word of mouth, so that often the holding of community gathering activities can maintain and strengthen local wisdom itself.

The efforts of mitigating and overcoming conflicts with tigers which is an adaptation process of the prevailing traditional rules and the phenomenon of conflict with elephants. Strengthening efforts to mitigate and manage conflicts with wildlife independently (based on local wisdom) must still be maintained. It is necessary to consider the management of reserve funds as compensation if there is a high conflict intensity and the impact of a large loss especially if it has claimed lives.

We realize role of customary law which prohibits wildlife hunting activities will have a good impact on the conservation of Sumatran tigers. We strongly recommend that this model of natural resource management in our research location (based on good local wisdom) be implemented in other areas, especially in areas that have high human-tiger intensity and high density of tiger in human-dominated area. Strengthening local wisdom with appropriate rules must be implemented in another Unprotected Areas in Leuser-Ulu Masen Landscape to make sure the human and tiger can live in harmony.

\section{Acknowledgments:}

This study is funded by Forum HarimauKita for selected students, based on collaboration of Directorate of Biodiversity Conservation, Director General of Natural Resources Conservation and Ecosystem- KLHK and GEF UNDP in project "Transforming Effectiveness of Biodiversity Management on Sumatran Priority Landscapes". We also thank to all of the people in Mukim Lutueng and our informants who have helped us in implementing this study.

\section{References}

[1] E. A. Macdonald, D. Burnham, A. E. Hinks, A. J. Dickman, Y. Malhi, and D. W. Macdonald, "Conservation inequality and the charismatic cat: Felis felicis," Glob. Ecol. Conserv., vol. 3, pp. 851866, Jan. 2015.

[2] C. Albert, G. M. Luque, and F. Courchamp, "The twenty most charismatic species," PLoS One, vol. 13, no. 7, p. e0199149, Jul. 2018.

[3] J. Goodrich et al., "Panthera tigris," The IUCN Red List of Threatened Species 2015: e. T15955A50659951, 2015. [Online]. Available: http://dx.doi.org/10.2305/IUCN.UK.20152.RLTS.T15955A50659951.en. [Accessed: 21-Nov-2018].

[4] F. Courchamp, I. Jaric, C. Albert, Y. Meinard, W. J. Ripple, and G. Chapron, "The paradoxical extinction of the most charismatic animals," PLOS Biol., vol. 16, no. 4, p. e2003997, Apr. 2018. 
[5] H. T. Wibisono and W. Pusparini, "Sumatran tiger (Panthera tigris sumatrae): a review of conservation status.," Integr. Zool., vol. 5, no. 4, pp. 313-323, Dec. 2010.

[6] I. A. Haidir, W. R. Albert, I. M. R. Pinondang, T. Ariyanto, F. A. Widodo, and Ardiantiono, Panduan Pemantauan Populasi Harimau Sumatera. Jakarta: DITJEN KSDAE, 2017.

[7] World Bank, "Global tiger recovery program (2010-2022) (English)," Washington, DC, 2011.

[8] Global Tiger Initiative Secretariat, Managing Tiger Conservation Landscapes Habitat Connectivity: Managing Tiger and Threats and Possible Solutions. Experiences from Bangladesh, India, Indonesia, Malaysia, Myanmar, Nepal, Thailand, and Vietnam, no. October. Washington, D.C, 2012.

[9] J. Goodrich, Human-tiger conflict: A review and call for comprehensive plans, vol. 5. 2010.

[10] J. Walston et al., "Bringing the Tiger Back from the Brink-The Six Percent Solution," PLoS Biol., vol. 8, no. 9, p. e1000485, Sep. 2010.

[11] A. Mardhiah, S. Supriatno, and D. Djufri, "Pengelolaan Hutan Berbasis Kearifan Lokal dan Pengembangan Hutan Desa di Mukim Lutueng Kecamatan Mane Kabupaten Pidie Provinsi Aceh," Biot. J. Ilm. Biol. Teknol. dan Kependidikan, vol. 4, no. 2, pp. 128-135, Feb. 2018.

[12] M. J. Struebig et al., "Addressing human-tiger conflict using socio-ecological information on tolerance and risk," Nat. Commun., vol. 9, no. 1, p. 3455, Dec. 2018.

[13] D. Irvansyah et al., Standar Operasional Prosedur (SOP) Penanganan Konflik antara Manusia dengan Harimau di Provinsi Aceh. Banda Aceh: BKSDA Aceh, 2017.

[14] Mukim Lutueng, Qanun Mukim Lutueng Kecamatan Mane Kabupaten Pidie No 1 Tahun 2012. Indonesia: http://bit.ly/qanun-mukim-lutueng, 2012.

[15] Y. R. Tjamin, F. M. Mangunjaya, I. S. Tobing, and G. Praharawat, "The attitude, norm and perception of communities towards Sumatran tiger conservation initiatives in Aceh," J. Indones. Hist., vol. 5, no. 1/2, pp. 10-15, Dec. 2017.

[16] K. Berliani, H. S. Alikodra, B. Masy'ud, and M. D. Kusrini, "Bioekologi Gajah Sumatera (Elephas Maximus Sumatranus) pada Konflik Gajah-Manusia Di Provinsi Aceh,” Pros. Biot., vol. 4, no. 1, Apr. 2018.

[17] I. N. Qomariah, T. Rahmi, Z. Said, and A. Wijaya, "Conflict between human and wild Sumatran Elephant (Elephas maximus sumatranus Temminck, 1847) in Aceh Province, Indonesia," Biodiversitas J. Biol. Divers., vol. 20, no. 1, pp. 77-84, Dec. 2018.

[18] A. C. Kitchener et al., "A revised taxonomy of the Felidae: The final report of the Cat Classification Task Force of the IUCN Cat Specialist Group," Cat News, no. Special Issue 11, p. 80, 2017.

[19] F. A. V. St. John et al., "Intention to kill: Tolerance and illegal persecution of Sumatran tigers and sympatric species," Conserv. Lett., vol. 11, no. 4, p. e12451, Jul. 2018.

[20] R. Hamdani Harahap and Humaizi, "Local wisdom in preservation of Lake Toba ecosystems (study on Toba Lake community in the Village of Silalahi I, Sub District of Silahisabungan, Dairi Regency, North Sumatera Province)," IOP Conf. Ser. Earth Environ. Sci., vol. 126, no. 1, p. 012122, Mar. 2018. 